\title{
ASSOCIATION OF COSTUMER VALUE CHAIN ANALYSIS TO QUALITY FUNCTION DEPLOYMENT: DIFFERENT IDENTIFIED COSTUMERS AND REQUIREMENTS ON DEVELOPMENT OF CPM \\ DEVICE
}

\author{
Raffaela Leane Zenni Tanure \\ UFRGS - Federal University of Rio Grande do Sul, Brazil \\ E-mail: raffaelat@gmail.com \\ Aline Marian Callegaro \\ UFRGS - Federal University of Rio Grande do Sul, Brazil \\ E-mail: nimacall@gmail.com \\ Amanda Sória Buss \\ UFRGS - Federal University of Rio Grande do Sul, Brazil \\ E-mail:di.amandabuss@gmail.com \\ Márcia Elisa Soares Echeveste \\ UFRGS - Federal University of Rio Grande do Sul, Brazil \\ E-mail: echeveste@producao.ufrgs.br \\ Istefani Carísio de Paula \\ UFRGS - Federal University of Rio Grande do Sul, Brazil \\ E-mail: istefani@producao.ufrgs.br \\ Carla Schwengber ten Caten \\ UFRGS - Federal University of Rio Grande do Sul, Brazil \\ E-mail: tencaten@producao.ufrgs.br
}

Submission: $29 / 04 / 2013$ Accept: 20/05/2013

\section{ABSTRACT}

This study aims to present the differences between the use of QFD and its association with CVCA tool in the development of a CPM device for elbow and forearm rehabilitation. To achieve this goal, the study was divided into three steps. The development of a conceptual model that integrates the proposed CVCA + QFD tool for application in the health device development was done in the first step. The second step consisted of applying the proposed model, referring to the QFD method using 8 matrixes: quality matrix, product, characteristics of the parts, process, process parameters, human resources, infrastructure and costs matrix. The proposed conceptual 
model was employed fully in the third step, allowing the comparison between the methods. The results enabled to identify a discrepancy between the critical costumers in the use of mentioned methods. Customers were limited to the direct and indirect users in the QFD application: the patient, physician and physical therapist. This list got a considerable increase when CVCA was applied: the clinical engineering, product engineering, process and reliability engineering, project and product managers, financial sector, quality system and regulatory issues. These results show the importance of analyzing the supply chain systemically in order to consider all stakeholders to the CPM device development. Thus, needs and relationships delineation of all process customers can be done.

Keywords: quality management; QFD; CVCA; product development; continuous passive motion.

\section{INTRODUCTION}

New technologies are revolutionizing services delivery since the last half century. The health sciences seek to resolve research problems integrating multidisciplinary teams involving engineering skills and other physical sciences into life sciences (SHINE, 2004). This integration is visible in the health products development, such as devices for the application of continuous passive motion (CPM) in the human body's joints, such as the elbow and forearm. These devices are used in post-operative, post-trauma of joint injuries and cartilage avascular healing (MAVROIDIS et al., 2005) and (CALLEGARO, 2010).

According to Gadelha (2006), developed countries that compete in better conditions with advanced countries have associated endogenous basis of knowledge, learning and innovation with a strong industry. Zago (2004) states the acquisition of itself experience is essential to the planning of scientific development in health. As a result, Brazil needs to develop national technology to be able to compete or replace the imported technology.

Shine (2004) emphasizes the development of new devices for health, requires, besides multidisciplinary teams, and the costumer involvement in the value chain of the product. Martin et al. (2006) point out the identification of needs is important to the development of new products, when they are performed early in the process. These needs can ensure the incorporation of new features to prototypes with greater facility and lower cost. According to Rozenfeld et al. (2006), needs become functional 
DOI: 10.14807/ijmp.v4i1.79

requirements of a new product and, in accordance with Silva (2004), they contribute for the development of products with higher quality, safety and reliability.

Andrietta and Miguel (2002) believe the understanding the Voice of Customer (VOC), in others words, their needs, expectations, requirements and desires is a step of fundamental importance. It is in this stage that the VOC are translated on technical requirements, specifications, products, processes and services. Its understanding and exact translation can be obtained by using the Quality Function Deployment Method (QFD Method). Cheng (2003) asserts the QFD method seeks to coordinate the control and quality improvement, integrating them with the market. This method is widely known and applied in the development of several products in the world and it aims at the consensus attainment of agreed actions in development projects to facilitate participants' learning and understanding.

The involvement of customers of the product value chain in product development for health can be understood by the systemic approach of the value chain. This approach allows the viewing of the group of actors that integrates their knowledge and skills to develop products focused on individuals and organizations (KRUCKEN, 2009). Thus, the association of Customer Value Chain Analysis tool (CVCA) to QFD can assist in innovation and consequent creation of value to the health products. The CVCA tool helps in understanding the business unit, product value chain and identification of critical customers (DONALDSON et al., 2006), while the QFD method assists the requirements management, one of the fundamental activities in the product development process (ROZENFELD et al., 2006).

Based in this context, the need to identify the differences between the QFD method application in relation to its association with the CVCA tool is justified when they are used in the development of CPM device for elbow and forearm rehabilitation. Emphasizing differences in the identification of critical costumers of the device value chain and business units of this product as well the demanded quality and results of deployment of QFD matrices.

Thus, this paper aims to present differences between the use of QFD and its association with CVCA tool in the development of CPM device for elbow and forearm rehabilitation. The structure comprises the following sections: (i) the literature review on the research topic; (ii) procedures used to reach the proposed objective, (iii) results and discussion, and (iv) study conclusions. 
DOI: 10.14807/ijmp.v4i1.79

\section{LITERATURE REVIEW}

This section presents definitions and theoretical foundations on the development of products in health, CVCA and QFD, which support this study.

\subsection{Product Development for Health}

The growing technification procedures for health makes this area one of the most dynamic in relation to the absorption of new technologies produced and consumed according to the market logic. Technological advances are related to the introduction of information technology, modern and sophisticated devices that benefited and allowed speed in the fight against diseases (BARRA et al., 2006).

The device industry related to the health field is characterized by a strong interdisciplinary content, in which the involvement of health specialists is crucial to the making of innovations. They give a support to identify needs and possibility of new devices, creating the first prototype and decisive improvement in the development of the devices (ALBUQUERQUE and CASSIOLATO, 2002). Furthermore, Back et al. (2008) assert that differentiated products of high quality are achieved primarily with the high quality of the product design, which is only achieved with teams that integrate different and relevant knowledge's to product design development.

The use of different technologies has increased in Physical Therapy as well as the interest increasing of professionals in this field. Physical Therapists use devices from simple to complex to assist in the kinetic-functional diagnostics, in the prescription, the planning, the managing, the analyzing, the monitoring and the evaluation of treatment (WALDROP, 2003). According to Cooper et al. (2008), the technology used to assist the physical therapeutic treatment qualifies the therapy received by the subject and it improves his engagement with the treatment. The computerized technology assists the patient in performing movements that require assistance of the Physical Therapist. Continuous Passive Motion devices (CPM) are used in the rehabilitation of patient's limb joints (LENSSEN et al., 2008). The use of these devices assists the performing of passive joint movements continuously during the initial phase of rehabilitation (HEBERT et al., 2003). A prototype of CPM device for elbow and forearm rehabilitation can be viewed in the Figure 1 (1); Figure 1 (2) shows how the patient positions his arm at the device. 


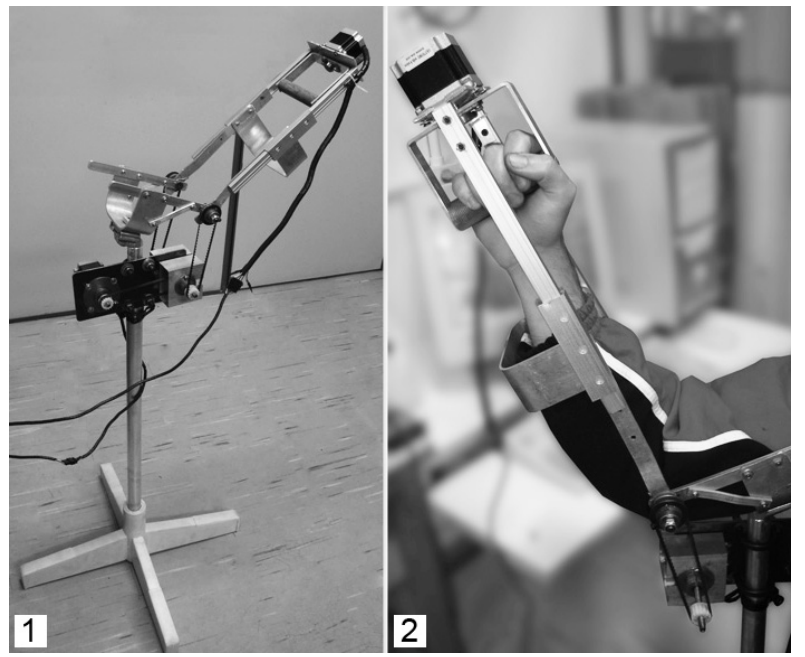

Figure 1: (1) Prototype of Computerized CPM Device for Elbow and Forearm Rehabilitation; (2) Arm positioned on CPM.

Source: Callegaro (2010).

Studies about CPM devices are more advanced for lower limb joints, especially the knee (SPERB, 2006) and (MAVROIDIS et al., 2005). But there is a demand by professionals work in elbow and forearm rehabilitation for CPM devices to help these joints treatment, indicating the need for researches focused on the upper limbs (MAVROIDIS et al., 2005) and (CALLEGARO et al., 2011).

\subsection{Customer Value Chain Analysis - CVCA}

Value is a concept created by the own value chain that guides each organization or tool management, it is crucial to the survival of a business model (PETETIN et al., 2010). Economy, intellectual capital and intangible assets are included in the values networks of the business model knowledge (ALLEE, 2000). Miccoli (2004) adds there are two types of influencers interfering in the life and values of organizations: external - owners, associates (suppliers, customers, partners and competitors), the employees' associations, trade unions and the various audiences that surround them all; and internal - members of the organization themselves.

When it comes to an innovative product, values that will be created or destroyed by it are key factors in deciding upon its release. It is, therefore, essential the design team early in the process of product development define precisely what types of values a business model has (PETETIN et al., 2010), as well as parties involved in the product's life cycle - stakeholders - and their relationship with the product. That's because interested parties often have different perceptions, including when it concerns about understanding the value assigned by project management 
DOI: 10.14807/ijmp.v4i1.79

(DONALDSON et al., 2006). The CVCA is a tool allows, in the product definition phase, the identification in a comprehensive manner of relevant stakeholders, relationships with each other and their role in the product life cycle. This increases the team's ability to recognize the diverse requirements of the product and priorities to define the product.

CVCA is a strategic and tactical tool, implemented from the organization's business model which has seven stages: i) to define the initial business model and its assumptions; ii) to delineate the parties involved with the product; iii) to determine how the parts relate; iv) to identify the relationships between the parties defining flows between them; v) to analyze the resulting CVC (customer value chain) to determine the critical customers and their propositions; vi) to include the information in PDA (Product Definition Assessment); and vii) to use the results of CVCA in the product project process (DONALDSON et al., 2006). These authors state that the CVCA's seventh stage consists in using the results of the value network analysis for the application of other tools such as Failure Mode and Effect Analysis (FMEA); Design for X (DfX); Quality Function Deployment (QFD) and others.

\subsection{Quality Function Deployment - QFD}

Quality Function Deployment (QFD) can be defined, according to Akao (1996), as a method aims to establish the quality of the project and also to obtain customer satisfaction. The complete conceptual model, originally developed in Japan, consisted of a total of 22 matrices in 27 implementation steps, covering the deployment of four dimensions: quality, technology, cost and reliability. Since its construction depends entirely on the project objectives and the product nature, among other characteristics, has the possibility to adapt it (CHENG and MELO FILHO, 2007). An example of adaptation is the model of 7 matrices proposed by Ribeiro et al. (2001).

Particularly, in the medical field, subject of the present study, some applications were found as follows: i) application of the method in an approach to improving the service offered by a podiatry clinic to relocate operations to provide services more comprehensive and satisfactory for both physicians and patients (MAZUR et al., 1995); ii) understanding of customer requirements and their inclusion to continuous improvement of the quality of the services provided by the health care system (Radharamanan and Godoy, 1996); iii) QFD employed in developing a 
DOI: 10.14807/ijmp.v4i1.79

computational network service support for occupational therapists (HALLBERG et al., 1999); iv) method used in the design and development of a range of simple medical diagnosis with a high degree of precision (LIU et al., 2009); v) verification of the ability to plan for quality in family health units, through the use of QFD (VOLPATO et al., 2010); vi) application of QFD in order to improve outpatient services for elderly patients (KUO et al., 2011).

Thus, all the applications listed relate to the services sector in the medical field. A similar situation occurs in the studies developed in Brazil, and not just in this particular area, but in general. Sassi and Miguel (2002) have shown that the use of QFD in Brazilian territory is more frequent in the service sector with the goal of improving the provision of services and, consequently, increase customer satisfaction.

\section{METHODOLOGY}

This research is characterized as a qualitative study. Based on its overall objectives, it is classified as exploratory as it aims to provide greater familiarity with the problem and thus make it more explicit (GIL, 2002). The definition of methods and techniques involves the methodology used to achieve each specific goal and, consequently, the overall goal of the research. To achieve this goal, the study was divided into three steps. The first step consisted of applying the proposed model, referring to the QFD method using eight matrices: quality, product, parts characteristics, process, process parameters, human resources, infrastructure and costs. The development of a conceptual model that integrates the proposed CVCA + QFD tool for application in the development of health device occurred in the second step. The proposed conceptual model was employed fully in the third step, allowing the comparison between the methods.

\subsection{First Step - Application of Adapted QFD}

The first step consisted of using a adapted conceptual QFD model from Ribeiro et al. (2001), which employs the use of seven matrices, as follows: quality, product, parts characteristics, process, process parameters, human resources, infrastructure and costs (Figure 2). Instead of seven matrices, eight were applied in this research, because the human resources and infrastructure matrix was deployed into two, i.e. human resources matrix and infrastructure matrix. The identification of the target population to be studied occurred prior to the application of the matrices, 
DOI: $10.14807 /$ ijmp.v4i1.79

and relied on the criteria of prior knowledge of device or possible relationship to the value chain of the device in question, according to the perception of researchers.

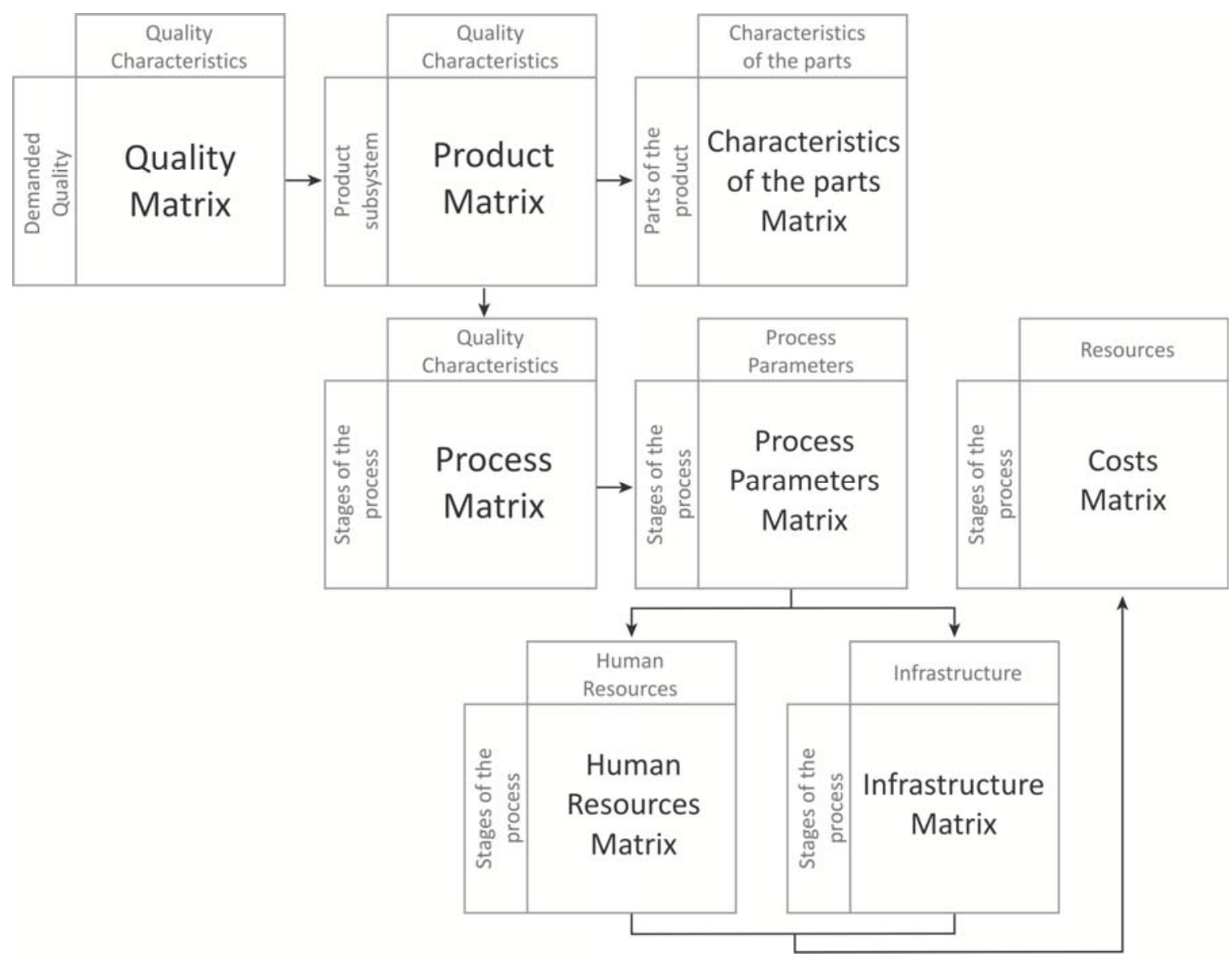

Figure 2: QFD conceptual model adapted from Ribeiro et al. (2001). Source: primary.

\subsection{Second Step - CVCA+QFD: The Proposed Conceptual Model of the CVCA Associated with QFD}

A model that integrates CVCA and QFD tools is proposed in this step (Figure 3). The CVCA tool facilitates the identification of critical customers and carries out analysis of the value chain.

First, one analyzes the value chain using the steps of the CVCA. To that end, there was an adaptation of the steps proposed by Donaldson et al. (2006), i.e. used the first five steps that actually related to the customer's value chain. The last two refer to the use of information obtained in the definition of product evaluation and design process. Therefore, the steps were followed:

- Define the initial business model and assumptions;

- Delineate the pertinent parties involved with the product; 
INDEPENDENT JOURNAL OF MANAGEMENT \& PRODUCTION (IJM\&P)

http://www.ijmp.jor.br

v. 4, n. 1, January - June 2013.

ISSN: 2236-269X

DOI: $10.14807 /$ ijmp.v4i1.79

- Determine how the parties are related to each other;

- Identify the relationships among the parties by defining flows between them;

- Analyze the resulting Customer Value Chain to determine critical customers and their value propositions (DONALDSON, 2006).

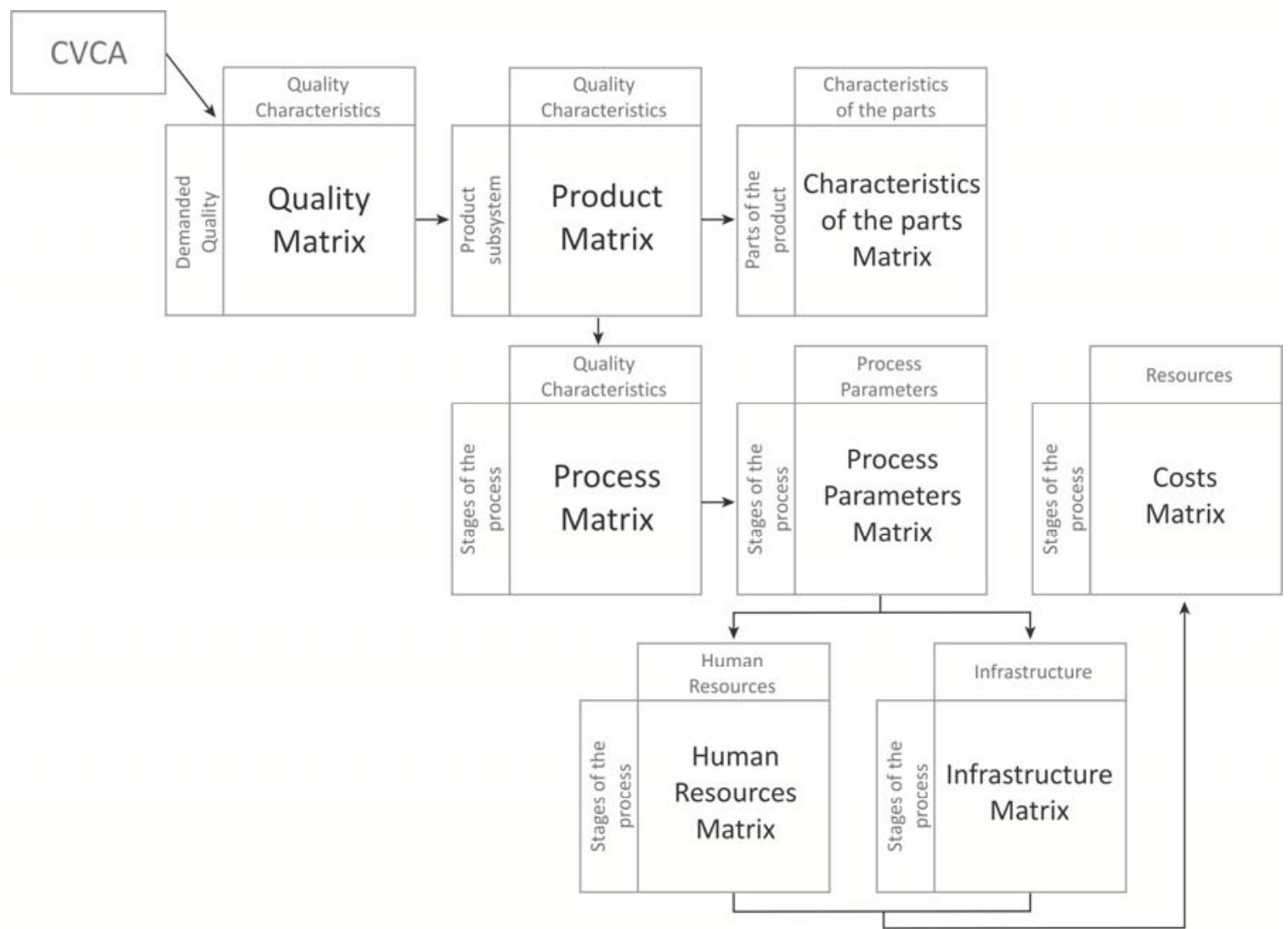

Figure 3: CVCA+QFD model for health product development. Source: primary.

After identifying critical customers, the remaining steps which coincide with the conceptual model of QFD adapted from Ribeiro et al. (2001) were applied normally until the construction of the quality matrix.

\subsection{Third Step - Application of CVCA+QFD}

The application of the proposed model CVCA+QFD in the development of a CPM machine for elbow and forearm rehabilitation was in a medical, physical therapy, and hospital products company of a city in the State of Rio Grande do Sul, Brazil. The company was selected because of the developed products technologies and the market areas provided synergies with those of the above-mentioned device. Discourse on the results in the following section. 
DOI: 10.14807/ijmp.v4i1.79

\section{RESULTS \& DISCUSSION}

This section presents and discusses the main differences identified in the QFD application related to its association with CVCA in the following steps: critical costumer's definition; demanded quality survey; demanded quality deployment, deployment of product and its parts, deployment of process and its parameter. The human resources deployment, infrastructure deployment and costs deployment are not discussed because there were no differences when compared with the first application. In other words, in the human resources matrix deployment, it was noted in both applications the production supervisor and the process and quality engineers play crucial roles to ensure compliance with the process specifications. In the infrastructure matrix, cutting machines were identified as the most important resources, because its excellence will provide quality in the essential parts of the final product. In the costs matrix, the molding process and the cuts finishing, assembly, polymers and fabrics cuts and finishing had the highest monthly costs.

\subsection{Critical costumers definition}

The present study revealed a discrepancy between the costumers considered critical, the association between the QFD and the CVCA tools had an effect on the customer's definition. The QFD application showed the costumers were limited to what was considered direct and indirect costumers: patient, physician and physical therapist. The costumers list of the association between the QFD and the CVCA tools had a considerable increase: product and process engineers, clinical and reliability engineering department; product managers; project control department; financial sector; product manager and regulatory affairs (Figure 4). Customers not mentioned during the application of the QFD method were incorporated in this second application, increasing the capacity of the project team of recognizing diversified product requirements and new priorities. These discrepancies allowed noticing that the QFD method refers to the meeting of the product functionalities, while the CVCA considers the system functionalities to which the product belongs. Thus the CVCA helps the research team in determining the critical customers for the application of the market research that aims at gathering data needed to define the demanded quality, the starting point for the QFD. 


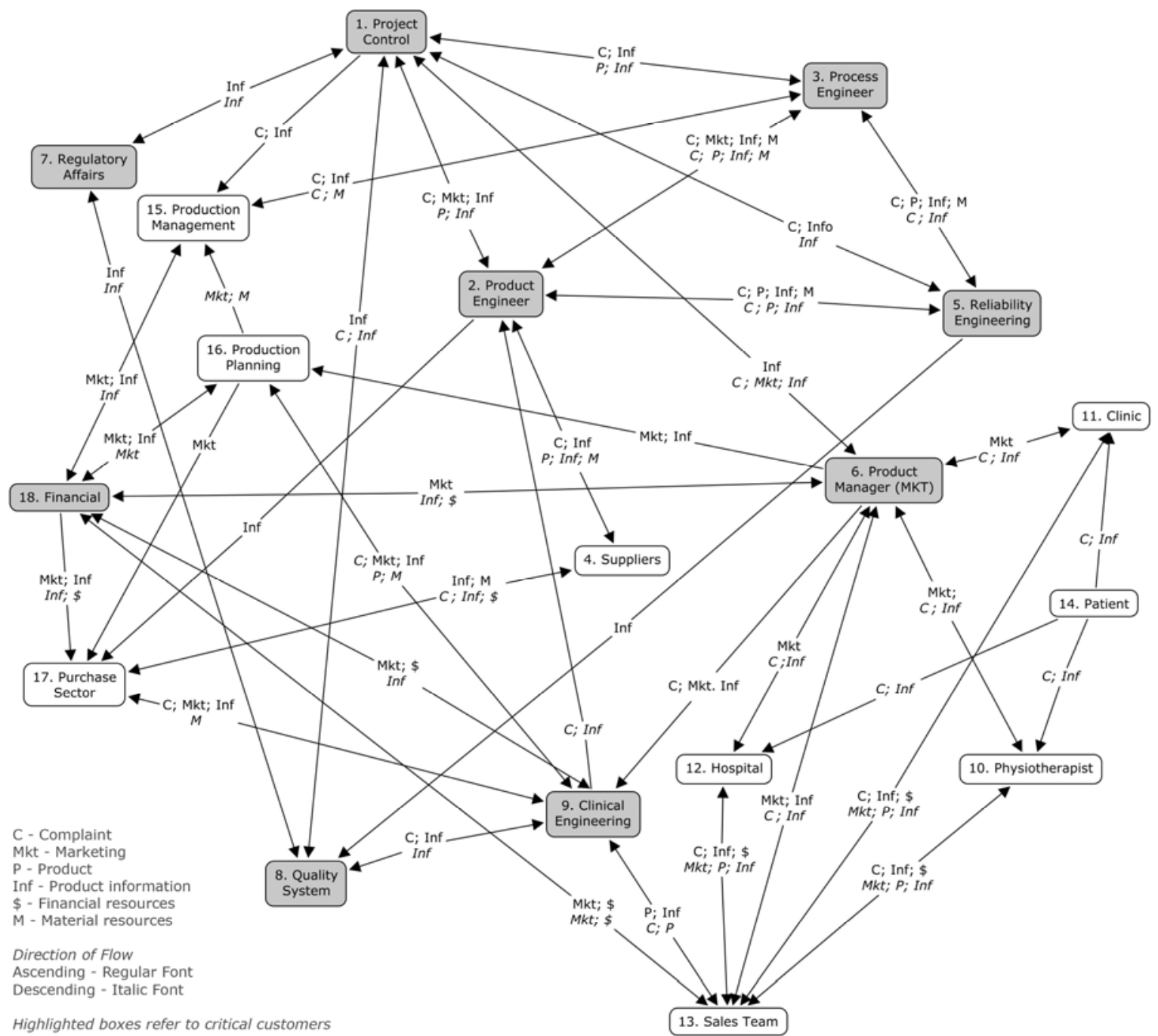

Figure 4: Results of CVCA application to product development in the health area. Source: primary

\subsection{Demanded Quality Survey}

The primary attributes 'aesthetics', 'material', 'components/elements', 'handling', 'ergonomics' and 'functions' identified in the QFD application were the same in the CVCA+QFD application. Secondary attributes differ in both applications (see Table 1). Differences were emphasized in the following attributes: i) 'aesthetics', the 'neutral color' appeared in the first application, it is missing in the second application, in which was identified the secondary attribute 'innovative'; ii) 'material', points the item 'breathable surface skin contact' in the first application, and 'trustworthy' in the second application, which are related to the reliability of the material used at the production; iii) 'components/elements' had in the first application 'reduced numbers of components', 'transport and storage container' and 'different energy sources', while in the second application, 'safe components', 'replacement parts guaranteed' and 'reduced maintenance' were identified; iv) primary attribute 
DOI: 10.14807/ijmp.v4i1.79

'handling', presents as secondary attributes 'silent' in the first application and 'dismountable' in the second; v) 'ergonomics', the main differences between both applications are between 'harmonic movements'/lateral supports for alignment' and 'patient's comfort'/'effective performance'; iv) 'functions', differ mainly at 'programmable functions' and 'applicable to various joints'.

The QFD application shows the attribute 'functions' has the greatest product's relative importance $(22,90 \%)$, and it is deployed in 'possible physiological range' (5,93\%), 'assistive, active and resistive programs' (5,67\%), 'programmable functions' $(5,42 \%)$ and 'simple interface' $(7,17 \%)$. The attribute 'ergonomics' $(21,50 \%)$ is deployed in 'harmonic movements' (7,62 \%), 'lateral supports for alignment' $(6,03 \%)$, 'not pose a risk to the user' (5,72\%), 'anthropometric adjust' $(5,44 \%)$, and, (see Table 1).

The CVCA+QFD application shows in the secondary levels the attribute 'ergonomics' had the greatest product relative importance $(19,10 \%)$, deployed in 'patient and operator safety' $(4,88 \%)$, 'effective performance' $(4,88 \%)$, 'anthropometric adjust' $(4,78 \%)$, and 'patient's comfort' $(4,58 \%)$. This attribute is followed by 'functions' and 'aesthetics', both with product is relative importance of $17,90 \%$. The attribute 'functions' is deployed in 'simple and intuitive interface' $(5,72 \%)$, 'possible physiological amplitude' $(4,67 \%)$, 'multiple functions' $(4,35 \%)$, 'applicable to various joints' (3,67\%), while the attribute 'aesthetics' is deployed in 'compact and portable' (6,62\%), 'organic design' (4,37\%), 'innovative' $(3,88 \%)$, and 'discrete' $(1,84 \%)$ (see Table 1).

The comparison of attributes identified in the demanded quality in both QFD and CVCA+QFD showed in Table 1 highlights the demanded-quality importance index is adjusted using two different factors. The first factor is used to consider the relevance of each item, considering its importance to the company strategy and the second factor is used to consider the company competition position in the market in comparison to a benchmarking organization. The result is the Demanded-quality Importance Index Adjusted (IDi*). 
ISSN: 2236-269X

DOI: $10.14807 /$ ijmp.v4i1.79

Table 1 - Comparison of attributes identified in the demanded quality in both QFD and CVCA+QFD

\begin{tabular}{|c|c|c|c|c|c|c|}
\hline 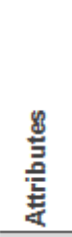 & Demanded Quality (QFD) & 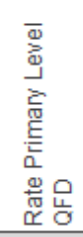 & $\begin{array}{l}0 \\
4 \\
0 \\
* \\
0\end{array}$ & Demanded Quality (CVCA + QFD) & 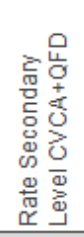 & $\begin{array}{l}0 \\
4 \\
0 \\
+ \\
+ \\
0 \\
0 \\
0 \\
* \\
0\end{array}$ \\
\hline \multirow{4}{*}{$\begin{array}{l}\frac{8}{8} \\
\frac{5}{5} \\
\frac{5}{8} \\
4\end{array}$} & Neutral color (similar to the skin) & 0,114 & 0,0161 & Innovative & 0,179 & 0,0388 \\
\hline & Organic form & & 0,0277 & Organic design & & 0,0437 \\
\hline & Compact & & 0,0397 & Compact and portable & & 0,0662 \\
\hline & Discrete & & 0,0154 & Discrete & & 0,0184 \\
\hline \multirow{4}{*}{ 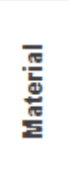 } & Soft surface skin contact & 0,138 & 0,0480 & Soft, breathable and not alergic surface skin contact & 0,151 & 0,0511 \\
\hline & Breathable surface skin contact & & 0,0342 & Trustworthy & & 0,0410 \\
\hline & Easy to clean / Asespsis & & 0,0350 & Easy to clean / Asespsis & & 0,0361 \\
\hline & Resistant to conditions of use and maintenano & & 0,0488 & Resistant to conditions of use and maintenance & & 0,0534 \\
\hline \multirow{4}{*}{ 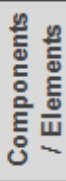 } & Reduced numbers of components & 0,134 & 0,0477 & Safe components & 0,130 & 0,0491 \\
\hline & Low weight of the equipment & & 0,0651 & Low weight of the equipment & & 0,0540 \\
\hline & Transport and storage container & & 0,0164 & Replacement parts guaranteed & & 0,0276 \\
\hline & Different energy sources & & 0,0322 & Reduced maintenance (do not require specific technical ca & are) & 0,0399 \\
\hline \multirow{4}{*}{ 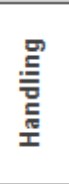 } & Easy to store & 0,171 & 0,0280 & Easy to store & 0,169 & 0,0267 \\
\hline & Transport through wheels or car & & 0,0418 & Easy to transport (accessory) & & 0,0427 \\
\hline & Silent & & 0,0550 & Dismountable & & 0,0344 \\
\hline & Intuitive use & & 0,0632 & Easy to assembly, to install, to configure, to adjust and to us & & 0,0486 \\
\hline \multirow{4}{*}{ 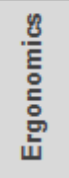 } & Anthropometric adjust & 0,215 & 0,0544 & Anthropometric adjust & 0,191 & 0,0478 \\
\hline & Harmonic movements & & 0,0762 & Patient and operator safety & & 0,0488 \\
\hline & Lateral supports for alignment & & 0,0603 & Patient's comfort & & 0,0458 \\
\hline & Not pose a risk to the user & & 0,0572 & Effective performance & & 0,0488 \\
\hline \multirow{4}{*}{ 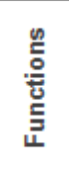 } & Possible physiological range & 0,229 & 0,0593 & Possible physiological amplitude & 0,179 & 0,0467 \\
\hline & Assistive, active and resistive programs & & 0,0567 & Multiple functions & & 0,0435 \\
\hline & Programmable functions & & 0,0542 & Applicable to various joints & & 0,0367 \\
\hline & Simple interface & & 0,0717 & Simple and intuitive interface & & 0,0572 \\
\hline
\end{tabular}

Source: primary

\subsection{Demanded Quality Deployment}

The QFD application analysis demonstrates the main demanded qualities are 'harmonic movements' and 'simple interface', associated to 'ergonomics' and 'functions', respectively. The least valued qualities demanded by the costumer are related to the 'aesthetics', and they are 'discrete' and 'neutral color'. Thus, according to the results, it's not necessary to make great efforts towards the appearance of the product, since this is little appreciated by the customer and will not contribute to its further acceptance in the market.

Main demanded qualities in the CVCA+QFD application are 'compact and portable' ('aesthetic') and 'simple and intuitive interface' ('functions'). The least valued qualities demanded by the critical customers are 'discrete' ('aesthetic'), 'easy to store' ('handling'), and 'replacement parts guaranteed' ('components/elements'). 
DOI: $10.14807 /$ ijmp.v4i1.79

This application differs from the first one especially because of the fact that the demanded quality 'aesthetic' was not valued (see Table 2).

The Table 2 shows the Importance of Quality Characteristics (IQj). The intensity of the relationship between the items of the demanded quality, the quality characteristics and the relative importance of the demanded quality were considered. The Index Importance of Quality Characteristics $\left(\mathrm{IQj}^{*}\right)$ was adjusted using a correction factor by assessing the difficulty of acting on the Quality Characteristics (Dj) and a competitive assessment with respect to Technical Characteristics (Bj).

Table 2 - Quality Matrix

\begin{tabular}{|c|c|c|c|c|c|c|c|c|c|c|c|c|}
\hline \multirow[b]{2}{*}{ 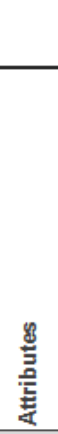 } & \multicolumn{6}{|c|}{$\begin{array}{l}\text { Quality Characteristics } \\
\text { (QFD) }\end{array}$} & \multicolumn{6}{|c|}{$\begin{array}{l}\text { Quality Characteristics } \\
\text { (CVCA+QFD) }\end{array}$} \\
\hline & Demanded Quality (QFD) & 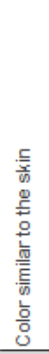 & 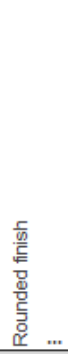 & 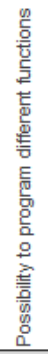 & 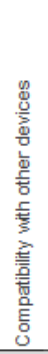 & $\begin{array}{l}0 \\
0 \\
0 \\
0\end{array}$ & Demanded Quality (CVCA + QFD) & 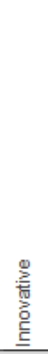 & 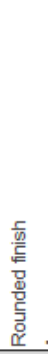 & 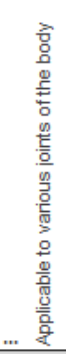 & 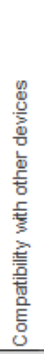 & $\begin{array}{l}0 \\
0 \\
0 \\
+ \\
0 \\
0 \\
0 \\
0 \\
0\end{array}$ \\
\hline \multirow{4}{*}{ 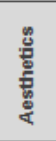 } & Neutral color (similar to the skin) & 9 & & & & 0,016 & Innovative & 9 & & 9 & 3 & 0,066 \\
\hline & Organic form & & 9 & & & 0,028 & Organic design & & 9 & & & 0,018 \\
\hline & Compact & & 1 & & & 0,040 & Compact and portable & & 1 & & & 0,051 \\
\hline & Discrete & 9 & 3 & & & 0,015 & Discrete & & 3 & & & 0,041 \\
\hline \multirow{4}{*}{ 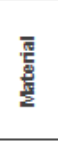 } & Soft surface skin contact & & 3 & & & 0,048 & Soft, breathable and not alergic surface skin contact & & 1 & & & 0,036 \\
\hline & Breathable surface skin contact & & & & & 0,034 & Trustworthy & & 1 & & & 0,053 \\
\hline & Easy to clean / Asespsis & 3 & 3 & & & 0,035 & Easy to clean / Asespsis & & 3 & & & 0,049 \\
\hline & Resistant to conditions of use and maintenance & & & & & 0,049 & Resistant to conditions of use and maintenance & & & & & 0,054 \\
\hline \multirow{4}{*}{ 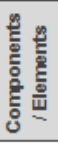 } & Reduced numbers of components & & & & & 0,048 & Safe components & & 9 & & & 0,028 \\
\hline & Low weight of the equipment & & & 1 & & 0,065 & Low weight of the equipment & & & & & 0,040 \\
\hline & Transport and storage container & & & & & 0,016 & Replacement parts guaranteed & & & & & 0,027 \\
\hline & Different energy sources & & & 1 & 1 & 0,032 & Reduced maintenance (do not require specific technical care) & & & & & 0,043 \\
\hline \multirow{4}{*}{$\begin{array}{l}\text { 畩 } \\
\text { 吾 } \\
\text { 空 }\end{array}$} & Easy to store & & & & 1 & 0,028 & Easy to store & & & & & 0,034 \\
\hline & Transport through wheels or car & & & 1 & & 0,042 & Easy to transport (accessory) & & & & & 0,049 \\
\hline & Silent & & & & & 0,055 & Dismountable & & & & & 0,048 \\
\hline & Intuitive use & & & 9 & 9 & 0,063 & Easy to assembly, to install, to configure, to adjust and to use & & & & & 0,049 \\
\hline \multirow{4}{*}{ 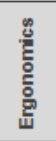 } & Anthropometric adjust & & & 3 & 3 & 0,054 & Anthropometric adjust & & & 9 & & 0,046 \\
\hline & Harmonic movements & & & 3 & & 0,076 & Patient and operator safety & & 9 & 9 & 3 & 0,049 \\
\hline & Lateral supports for alignment & & & 3 & & 0,060 & Patient's comfort & & & 3 & & 0.047 \\
\hline & Not pose a risk to the user & & 9 & 9 & 9 & 0,057 & Effective performance & & & 9 & 9 & 0,043 \\
\hline \multirow{4}{*}{ 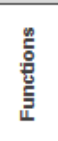 } & Possible physiological range & & & 3 & 3 & 0,059 & Possible physiological amplitude & & & 0,037 & & 0,037 \\
\hline & Assistive, active and resistive programs & & & 9 & 3 & 0,057 & Multiple functions & & & 0,057 & & 0,057 \\
\hline & Programmable functions & & & 9 & 9 & 0,054 & Applicable to various joints & 9 & & 9 & & 0,000 \\
\hline & Simple interface & & & 9 & 9 & 0,072 & Simple and intuitive interface & & & & 9 & 0,000 \\
\hline \multirow{4}{*}{ 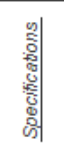 } & Importance of Quality Characteristics j IQj & 0,4 & 1,1 & 3,6 & 2,8 & & Importance of Quality Characteristics j IQj & 0,3 & 1,2 & 2,6 & 1,1 & \\
\hline & Difficulty of Practice (Dj) & 2,0 & 2,0 & 1,0 & 1,5 & & Difficulty of Practice $(D j)$ & 1,0 & 2,0 & 1,0 & 1,5 & \\
\hline & Competitive Analysis (Bj) & 0.5 & 1,0 & 0,5 & 1,0 & & Competitive Analysis (Bj) & 0.5 & 1,0 & 0,5 & 1,0 & \\
\hline & $1 Q j^{*}$ & 0,4 & 1,6 & 2,6 & 3,4 & & $1 Q j^{*}$ & 0.2 & 1,7 & 1,8 & 1,3 & \\
\hline
\end{tabular}

Source: primary

\subsection{Deployment of Product and its Parts}

In the product matrix at the QFD application, it was observed the necessity to prioritize the following parts of the product: 'support shaft', 'joystick', 'arm support', 'forearm support, 'base support', 'electronic system', 'mechanic system' and 
DOI: 10.14807/ijmp.v4i1.79

'software' (see Table 3). After the deployment and the prioritization or the parts, characteristics of parts matrix were filled and the greatest parts were crossed with their quality characteristics. Thus, it was possible to identify which characteristics must be controlled in the critical parts to provide the product quality. Through characteristics of the parts matrix, it was observed the need to prioritize the following characteristics of the parts of the product: 'support shaft angle', 'height adjustment', 'shaft thickness', and 'Joystick dimensions' (see Table 4).

Differently of previous tables, the Table 3 shows the Level of Importance of the Quality Characteristics $\left(\mathrm{IP}^{*}\right)$. It was adjusted using a correction factor by evaluating the difficulty of making modifications and the time required for modifications.

Table 3 - Product Matrix

\begin{tabular}{|c|c|c|c|c|c|c|c|c|c|c|c|c|c|c|c|}
\hline & \multicolumn{8}{|c|}{ Quality Characteristics (QFD) } & \multicolumn{7}{|c|}{ Quality Characteristics (CVCA+QFD) } \\
\hline $\begin{array}{l}\text { Product Parts } \\
\text { (QFD and } \\
\text { CVCA+QFD) } \\
\end{array}$ & 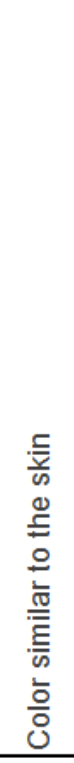 & 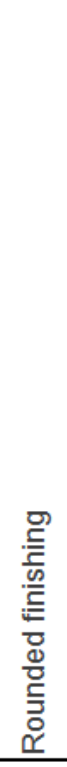 & 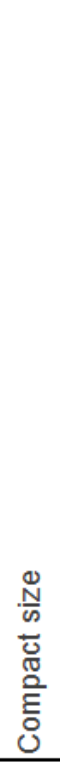 & 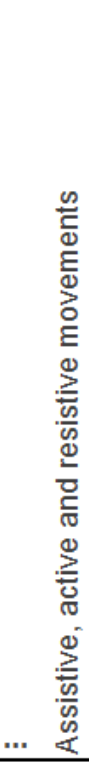 & 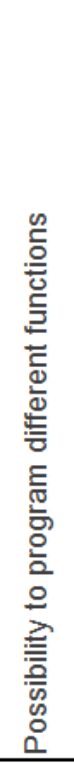 & 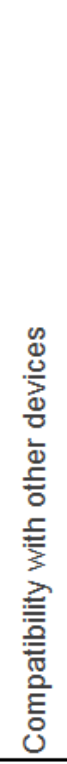 & $\begin{array}{l}0 \\
0 \\
0 \\
0 \\
0\end{array}$ & $\$$ & 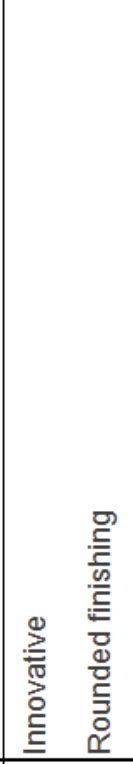 & 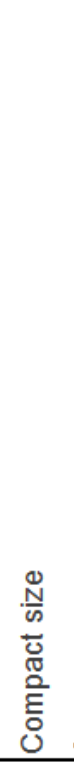 & 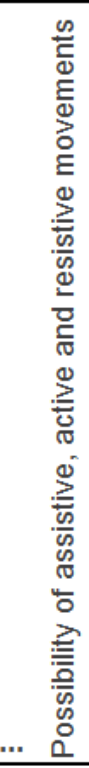 & 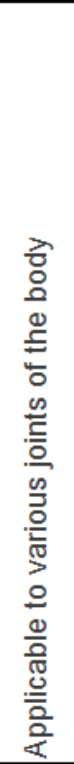 & 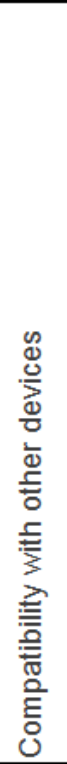 & $\begin{array}{l}0 \\
0 \\
0 \\
+ \\
0 \\
0 \\
0 \\
0 \\
k \\
0\end{array}$ & $\$$ \\
\hline $1 Q J^{*}$ & 0,39 & 1,55 & 1,64 & 1,54 & 2,56 & 3,41 & - & - & $0,482,26$ & 1,83 & 1,47 & 2,08 & 1,49 & - & - \\
\hline Base support & & 9 & 3 & & & 1 & 224 & 0,22 & 9 & 3 & & & 1 & 187 & 0,19 \\
\hline Support shaft & & 9 & 9 & & & 1 & 293 & 0,29 & 9 & 9 & & & 1 & 239 & 0,24 \\
\hline Arm support & 3 & 9 & 9 & 1 & & 1 & 246 & 0,25 & 9 & 9 & 1 & 9 & 1 & 245 & 0,24 \\
\hline Forearm support & 3 & 9 & 9 & 1 & & 1 & 246 & 0,25 & 9 & 9 & 1 & 9 & 1 & 245 & 0,24 \\
\hline Mechanic system & & 1 & 9 & 9 & & & 108 & 0,11 & 1 & 9 & 9 & 3 & & 104 & 0,10 \\
\hline Joystick & & 9 & 1 & 1 & & & 248 & 0,25 & 9 & 1 & 1 & 3 & & 212 & 0,21 \\
\hline Electronic system & & & & 9 & 9 & & 114 & 0,11 & 9 & & 9 & 9 & & 98 & 0,10 \\
\hline Software & & & & 9 & 9 & 9 & 107 & 0,11 & 9 & & 9 & 9 & 9 & 74 & 0,07 \\
\hline
\end{tabular}


Table 4 - Parts Characteristics Matrix Parts Characteristics (QFD)

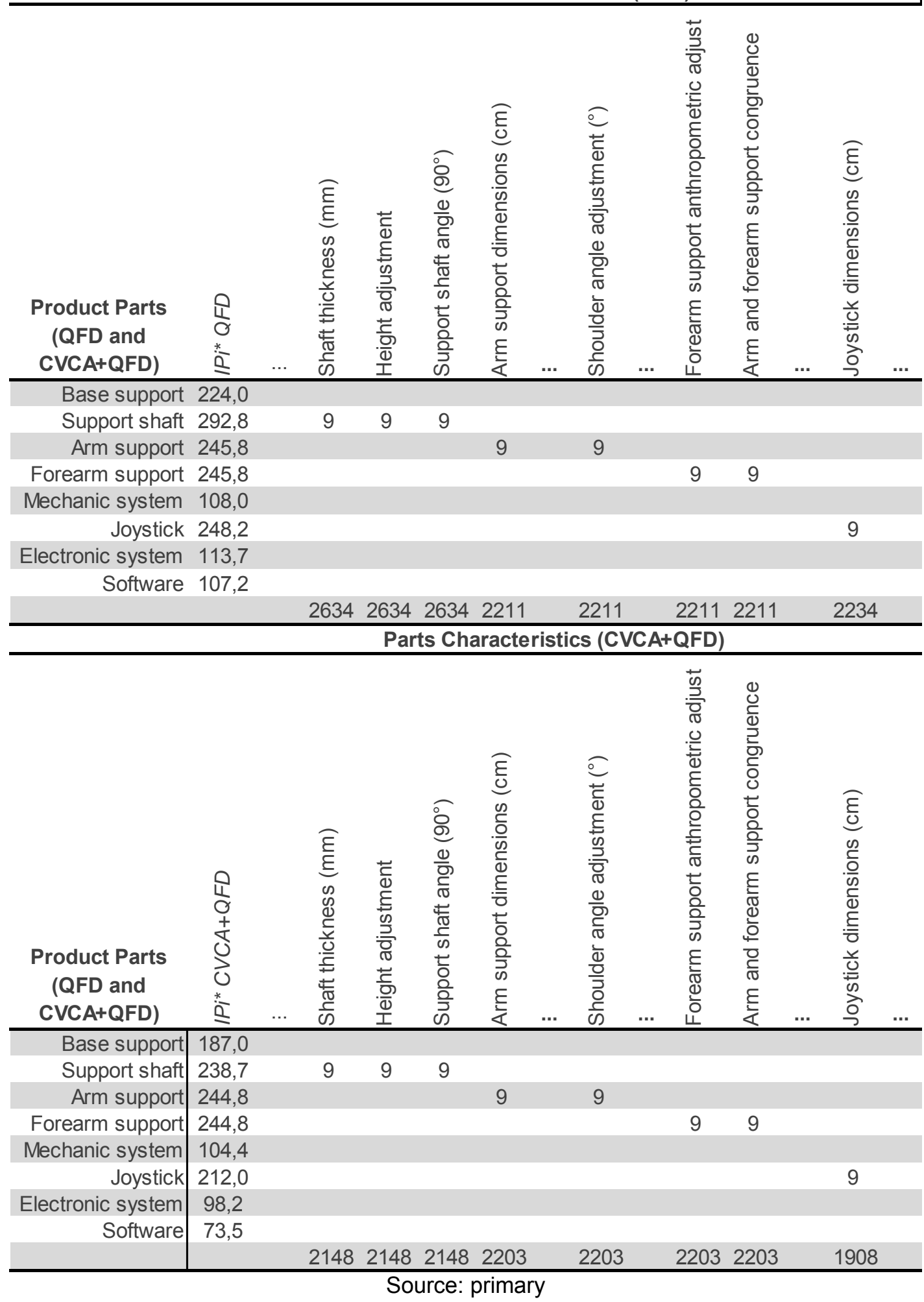

The CVCA+QFD application considers the descending order of priority of the parts is as follows: 'arm support' and 'forearm support', 'shaft support', 'joystick' and 'base support', 'mechanic system', 'electronic system' and 'software' (see Table 3). The main characteristics of parts must be prioritized in the device development are: 
DOI: 10.14807/ijmp.v4i1.79

'arm support dimensions', 'shoulder angle adjustment', 'forearm support anthropometric adjust' and 'arm and forearm support congruence' (see Table 4).

\subsection{Deployment of Process and its Parameters}

The process matrix deploys the product manufacture process, aiming to highlight the process associated with quality characteristics. The following descending order of priority of the manufacture process was identified in QFD application: 'aluminum profile cuts', 'assembly', 'receiving components', 'polymers and textile cuts', 'steel materials cuts', 'software programming', 'molding and finishing cuts', 'finishing', 'certification processes' and 'expedition' (see Table 5).

Table 5 - Process Matrix

\begin{tabular}{|c|c|c|c|c|c|c|c|c|c|c|c|c|c|c|c|c|}
\hline \multirow[b]{2}{*}{$\begin{array}{c}\text { Process Steps (QFD and } \\
\text { CVCA+QFD) }\end{array}$} & \multicolumn{8}{|c|}{ Quality Characteristics (QFD) } & \multicolumn{8}{|c|}{ Quality Characteristics (CVCA+QFD) } \\
\hline & 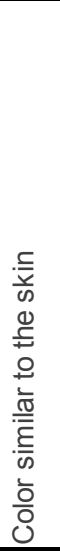 & 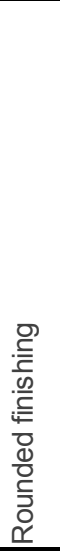 & 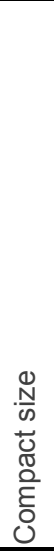 & 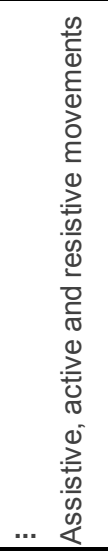 & 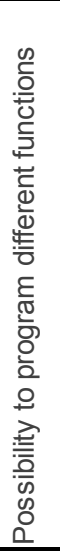 & 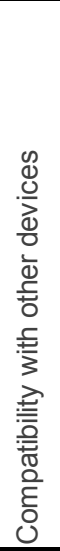 & 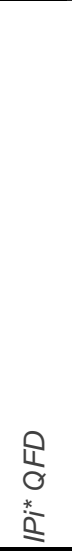 & ○ & 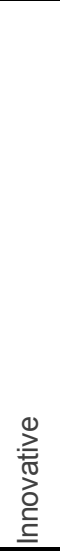 & 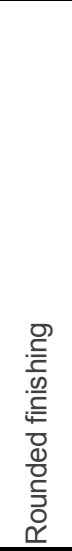 & 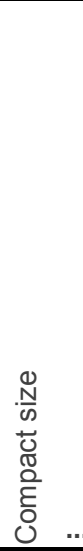 & 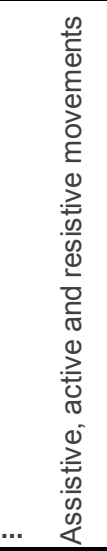 & 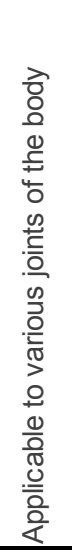 & 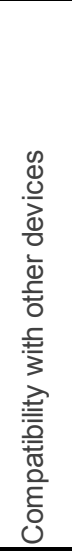 & $\begin{array}{l}0 \\
0 \\
0 \\
+ \\
0 \\
0 \\
0 \\
0 \\
* \\
0 \\
0\end{array}$ & 8 \\
\hline$I Q J^{*}$ & 0,4 & 1,6 & 1,6 & 1,5 & 2,6 & 3,4 & - & - & 0,48 & 2,26 & 1,83 & 1,47 & 2,08 & 1,49 & - & - \\
\hline Software programming & & & & 9 & 9 & 3 & 83 & 0,08 & 9 & & & 9 & 9 & 3 & 59 & 0,06 \\
\hline Receiving components & 9 & 9 & 1 & & & & 114 & 0,11 & & 9 & 1 & & & & 111 & 0,11 \\
\hline Aluminum profiles cuts & & 9 & 3 & & & & 250 & 0,25 & & 9 & 3 & & & & 225 & 0,22 \\
\hline Steel materials cuts & & 9 & 1 & & & & 86 & 0,09 & & 9 & 1 & & & & 90 & 0,09 \\
\hline Polymer and textile cuts & & 9 & 3 & & & & 105 & 0,10 & & 9 & 3 & & & & 113 & 0,11 \\
\hline Molding and finishing cuts & & 9 & 9 & & & & 78 & 0,08 & & 9 & 9 & & & & 80 & 0,08 \\
\hline Assembly & & & 3 & & & 3 & 181 & 0,18 & & & 3 & & & 3 & 183 & 0,18 \\
\hline Finishing & & 9 & & & & 1 & 59 & 0,06 & & 9 & & & & 1 & 71 & 0,07 \\
\hline Certification process & & & & & & 3 & 36 & 0,04 & & & & & & 3 & 32 & 0,03 \\
\hline Expedition & & & & & & 1 & 16 & 0,02 & & & & & & 1 & 23 & 0,02 \\
\hline
\end{tabular}

Source: primary

The same processes was observed in the CVCA+QFD application, but in the following descending prioritization order: 'aluminum profile cuts', 'assembly', 'polymers and textile cuts', 'receiving components', 'steel materials cuts', 'molding and finishing cuts', 'finishing', 'software programming', 'certification processes' and ‘expedition' (see Table 5).

The results of the process parameters matrix, which are directly related to the process' parameters and the stages of the manufacturing process of the CPM device under study, differed especially in the order of importance of four parameters when 
both QFD and CVCA+QFD applications are compared. In other words, after the matrix deployment it was observed, in the first application, the following descending order of importance of process parameters: 'cut dimensions', 'components positioning', 'cutting angle', 'number of failures/lack of compliance', 'quality of the received components', 'possibility and time of programming', 'molding angle', 'percentage of on-time deliveries', 'ANVISA's evaluation result', 'programs storage capacity', 'shipping time (logistics)' and 'percentage of well packaged device', respectively (see Table 7). The second application had an exchange of order between 'cutting angle' and 'number of failures/lack of compliance', and between 'possibility and time of programming' and 'molding angle' (see Table 7).

Table 6 - Process Parameters Matrix Process Parameters (QFD)

\begin{tabular}{|c|c|c|c|c|c|c|c|c|c|c|c|c|c|}
\hline \begin{tabular}{cc} 
Process Steps (QFD and & $\stackrel{0}{0}$ \\
CVCA+QFD) & \multirow{2}{*}{}
\end{tabular} & 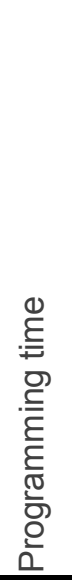 & 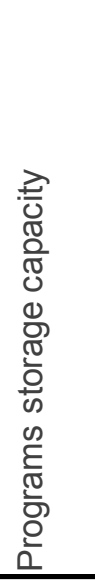 & 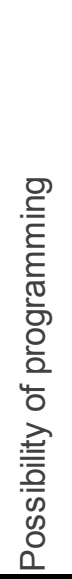 & 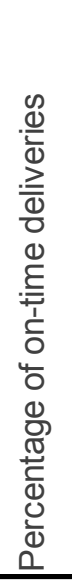 & 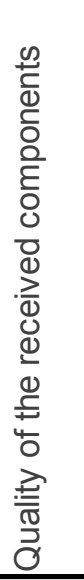 & 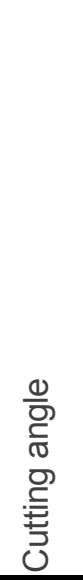 & 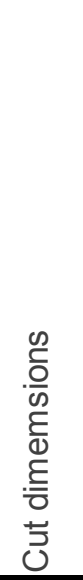 & 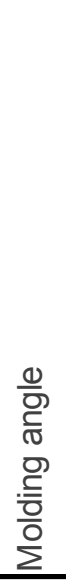 & 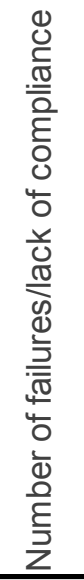 & 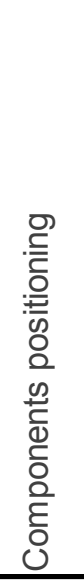 & 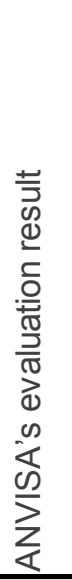 & 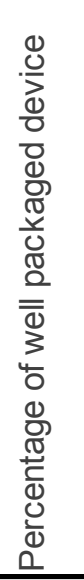 & 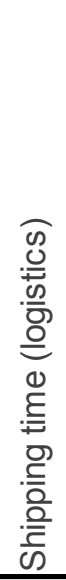 \\
\hline Software programming 83 & 9 & 3 & 9 & & & & & & & & & & \\
\hline Receiving components 114 & & & & 3 & 9 & & & & & & & & \\
\hline Aluminum profiles cuts 250 & & & & & & 3 & 9 & & & & & & \\
\hline Steel materials cuts 86 & & & & & & 3 & 9 & & & & & & \\
\hline Polymer and textile cuts 105 & & & & & & 3 & 9 & & & & & & \\
\hline Molding and finishing cuts 78 & & & & & & & & 9 & 9 & 9 & & & \\
\hline Assembly 181 & & & & & & & & & & 9 & & & \\
\hline Finishing 59 & & & & & & & & & 9 & & & & \\
\hline Certification process 36 & & & & & & & & & & & 9 & & \\
\hline Expedition 16 & & & & & & & & & & & & 3 & 9 \\
\hline & 748 & 249 & 748 & 342 & 1027 & 1321 & 3962 & 699 & 1231 & 2327 & 322 & 47 & 140 \\
\hline
\end{tabular}

Source: primary 
Table 7 - Process Parameters Matrix - cont. Process Parameters (CVCA+QFD)

Process Steps (QFD and CVCA+QFD)

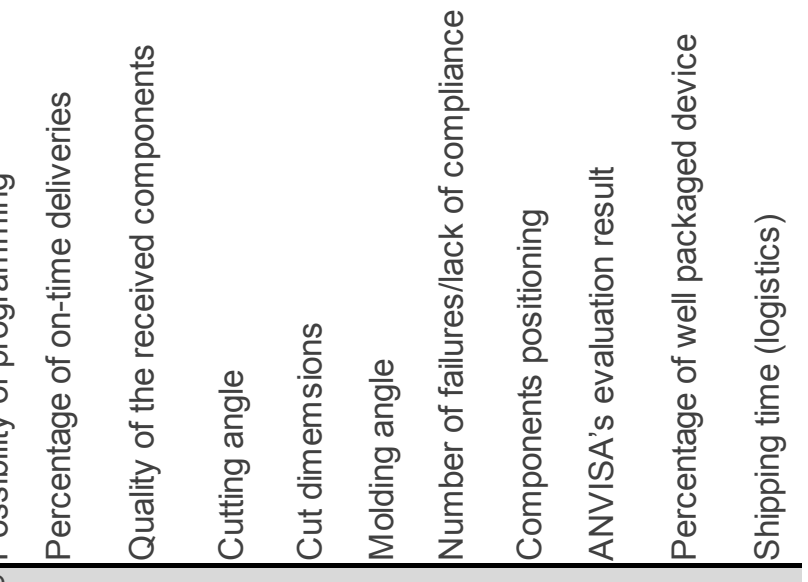

Software programming

Receiving components 111

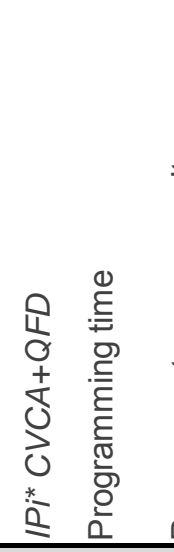

Aluminum profiles cuts 225

Steel materials cuts 90

Polymer and textile cuts 113

Molding and finishing cuts 80

Assembly 183

Finishing 71

Certification process 32

Expedition 23

39

$\begin{array}{ll}3 & 9 \\ 3 & 9 \\ 3 & 9\end{array}$

3

$\begin{array}{lll}9 & 9 & 9\end{array}$

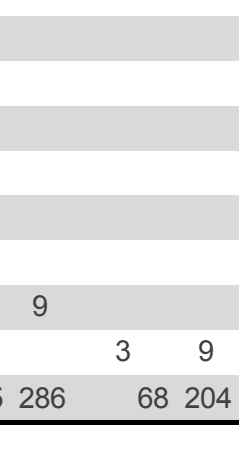

$531 \quad 177 \quad 531 \quad 333 \quad 1000$
Source: primary

\section{CONCLUSION}

This study aimed to present the differences between the use of an adapted method of QFD (compound of eight matrices) and its association with CVCA tool in the development of a CPM device for elbow and forearm rehabilitation.

Results allowed the identification of a discrepancy between the critical costumers and differences in the demanded quality attributes, as well as its prioritization. The importance of the product value chain analysis in a systematic way can be highlighted, considering all the involved parts in the development of a CPM device, besides the ones determined by the researchers themselves.

The differences of the applications allowed noticing that the QFD method refers to the meeting of the product functionalities, while the CVCA considers the system functionalities to which the product belongs. Thus the CVCA helps the research team in determining the critical customers for the application of the market research that aims at gathering data needed to define the demanded quality, the starting point for the QFD. Thus, the proposed association between the CVCA+QFD 
DOI: $10.14807 /$ ijmp.v4i1.79

methods was effective to identify needs of all process costumers, incorporating them in the product design and production process.

Such association can modify even the subsequent steps, such as the matrices of quality, parties and characteristics of the parts, for the prioritization of requirements can be differentiated, as observed in this study. The impacts are felt in the subsequent process and QFD resource matrices, equally. That is in reason of the distinct perceptions of the interested parties, including the understanding of the value assigned to the project. Although an exploratory study, the CVCA not only allowed this joint project but also reduced the complexity by highlighting the elements that represent value for stakeholders from the business model of a given organization.

This comparison was done in the product development process of one device specifically. The integration of the two methods and this same methods comparison are suggested for future studies, especially to those that aim the product development for health area, in order to confirm these results and detail more its impacts on the product project and its value network for different products.

\section{REFERENCES}

AKAO, Y. (1996). Introdução ao desdobramento da qualidade. Belo Horizonte: Fundação Christiano Ottoni, Escola de Engenharia da UFMG.

ALBUQUERQUE, E. M.; CASSIOLATO, J. E. (2002). As especificidades do sistema de inovação do setor saúde. Revista de Economia Política, v. 22, n. 4, p. 134-151.

ALLEE, V. (2000). Reconfiguring the value network. Journal of Business Strategy, V. 21, n. 4.

ANDRIETTA, J. M.; MIGUEL P. A. C. (2002). Os benefícios da utilização do método QFD no desenvolvimento de produto em uma empresa que adotou o Seis Sigma. Annals... In: XXII Encontro Nacional de Engenharia de Produção. Curitiba - PR: ABEPRO.

BACK, N.; OGLIARI, A.; DIAS, A.; SILVA, J.C (2008). Projeto integrado de produtos: planejamento, concepção e modelagem. Barueri: Manole.

BARRA, D. C. C.; NASCIMENTO, E.R.P; MARTINS, J.J.; ALBUQUERQUE, G.L.; ERDMANN, A.L. (2006). Evolução histórica e impacto da tecnologia na área da saúde e da enfermagem. Revista Eletrônica de Enfermagem, v. 08, n. 03, p. 422430.

CALLEGARO, A. M. (2010). Desenvolvimento um Equipamento computadorizado de Movimentação Passiva Contínua para cotovelo e antebraço [Dissertation]. Santa Maria (RS): Universidade Federal de Santa Maria. 
CHENG, L. C. (2003). QFD em desenvolvimento de produto: características metodológicas e um guia para intervenção. Revista Produção Online, v. 3, n. 2.

CHENG, L. C.; MELO FILHO, L. D. R. (2007). QFD: desdobramento da função qualidade na gestão de desenvolvimento de produtos (1st ed.). São Paulo: Blücher.

COOPER, R. A.; DICIANNO, B.E.; BREWER, B.; LOPRESTI, E.; DING, D.;

SIMPSON, R.; GRINDLE, G.; WANG, H. (2008). A perspective on intelligent devices and environments in medical rehabilitation. Medical Engineering \& Physics, v. 30, p. 1387-1398.

DONALDSON, K. M.; ISHII, K.; SHEPPARD, S. D. (2006). Costumer Value Chain Analysis. Londres: Springer-Verlag London Limited.

GADELHA, C. A. G. (2006). Desenvolvimento, complexo industrial da saúde e política industrial. Revista de Saúde Pública [online], v. 40, n.spe, p. 11-23.

GIL, A. C. (2002). Como elaborar projetos de pesquisa (4th ed.). São Paulo: Atlas.

HALLBERG, N.; JOHANSSON, M.; TIMPKA, T. (1999). A prototype computer network service for occupational therapists. Computer Methods and Programs in Biomedicine, v. 59, p. 45-54.

HEBERT, S.; BARROS, T. E. F.; XAVIER, R.; PARDINI JR, A. G. (2003). Ortopedia e traumatologia: princípios e prática (3rd ed.). Porto Alegre: Artmed.

KRUCKEN, L.. (2009). Design e território: valorização de identidades e produtos locais (1st ed.). São Paulo: Nobel, vol.1.

KUO, R-J.; WU, Y-H.; HSU, T-S.; CHEN, L-K. (2011). Improving outpatient services for elderly patients in Taiwan: a qualitative study. Archives of Gerontology and Geriatrics, v. 53, n. 2, p. 209-217.

LENSSEN, T. A. F. et al. (2008). Effectiveness of prolonged use of continuous passive motion (CPM), as an adjunct to physiotherapy, after total knee arthroplasty. BMC Musculoskeletal Disorders, v. 9, n. 60.

LIU, S-F.; LEE, Y.; HUANG, Y. (2009). A brief fatigue inventory of shoulder health developed by quality function deployment technique. Journal of Shoulder and Elbow Surgery, v. 18, p. 418-423.

MARTIN, J. L.; MURPHY, E.A.; CROWE, J.A.; NORRIS, B. (2006). Capturing user requirements in medical device development: The Role of Ergonomics,

Physiological Measurement, v. 27, n. 8, p. R49-R62.

MAVROIDS, C.; NIKITCZUK, J.; WEINBERG, B.; DANAHER, G.; JENSEN, K.; PELLETIER, P.; PRUGNAROLA, J.; STUART, R.; ARANGO, R.; LEAHEY, M.; PAVONE, R.; PROVO, A.; YASEVAC, D. (2005). Smart portable rehabilitation devices. Journal of Neuroengineering and Rehabilitation, v. 2, n. 18, p. 1-15.

MAZUR, G.; GIBSON, J.; BARRIES, B. (1995). QFD applications in health care and quality of worklife. Annals... In: International Symposium on Quality Function Deployment, JUSE (Union of Japanese Scientists and Engineers), Tokyo.

MICCOLLI, W. R. V. (2004). Sistematização das metodologias atuais de gerenciamento de projetos nas indústrias de grande porte da Grande Curitiba: um estudo de multi-casos [Dissertação]. Curitiba, PR. Universidade Federal do Paraná. 
PETETIN, F.; BERTOLUCI, G.; BOCQUET, J. C. (2010). A value approach in innovative product development: are conventional methods and tools sufficient? Annals... In: International Design Conference. Dubrovnik - Croatia.

RADHARAMANAN, R.; GODOY, L. P. (1996). Quality Function Deployment as applied to a health care system. Computers and Industrial Engineering, v. 31, n. 1/2, p. $443-446$.

RIBEIRO, J. L. D.; ECHEVESTE, M. E.; DANILEVICZ, Â. M. F. (2001). A utilização do QFD na otimização de produtos, processos e serviços. Porto Alegre, RS: FEENG/UFRGS, PPGEP/UFRGS.

ROZENFELD, H.; FORCELLINI, F. A.; AMARAL, D. C.; TOLEDO, J. C.; SILVA, S. L.; ALLIPRANDINI, D. H.; SCALICE, R.; K. (2006). Gestão de desenvolvimento de produtos: uma referência para a melhoria do processo. São Paulo: Saraiva.

SASSI, A. C.; MIGUEL, P. A. C. (2002). Análise de publicações sobre o QFD no desenvolvimento de serviços e produtos. Annals... In: XXII Encontro Nacional de Engenharia de Produção. Curitiba - PR.

SHINE, K. I. (2004). Technology and health. Technology in Society, v. 26, p. 137148.

SILVA, J. A. (2004). Desempenho do sistema de medição. Anais... In: Encontro para aqualidade de laboratórios. São Paulo: ENQUALAB.

SPERB, D. Q. (2006). Desenvolvimento de dispositivo programável de movimento passivo contínuo para membros inferiores [Dissertação]. Santa Maria (RS). Universidade Federal de Santa Maria.

VOLPATO, L. F.; Meneghim, M. C.; Pereira, A. C.; Ambrosano, G. M. B. (2010). Planejamento da qualidade nas unidades de saúde da família, utilizando o Desdobramento da Função Qualidade (QFD). Caderno de Saúde Pública, v. 26, n. 8, p. 1561-1572.

WALDROP, S. (2003). The future is now: technology and its impact on Physical Therapy. PT Magazine, p. 34-39.

ZAGO, M. A. A. (2004). Pesquisa clínica no Brasil. Ciência e Saúde Coletiva [online], v. 9, n. 2, p. 363-374. 